Historic, archived document

Do not assume content reflects current scientific knowledge, policies, or practices. 


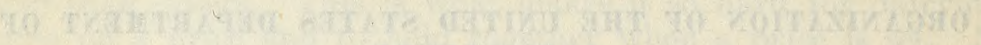

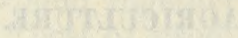




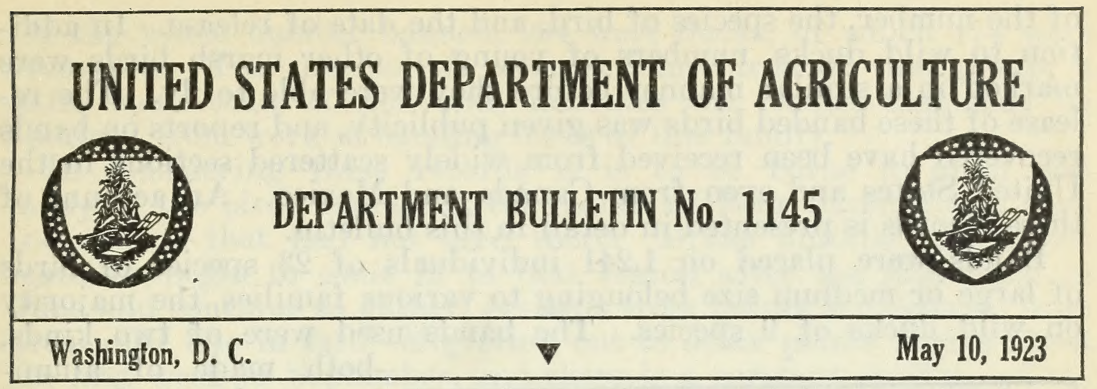

\section{MIGRATION RECORDS FROM WILD DUCKS AND OTHER BIRDS BANDED IN THE SALT LAKE VALLEY, UTAH.}

By Alexander Wetmore, Assistant Biologist, Division of Biological

Investigations, Bureau of Biological Survey.

Introduction Migration and occurrence records

Gadwall

Green-winged teal

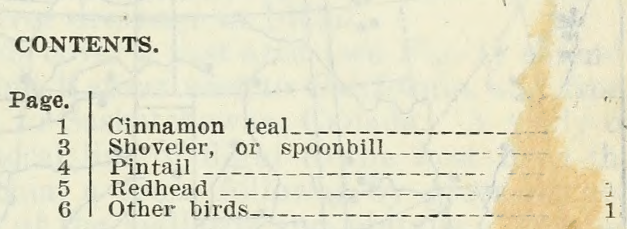

INTRODUCTION.

The Bear River marshes at the north end of Great Salt Li Utah (Pl. I, Fig. 1), a region highly attractive to wild ducks a d other waterfowl, are known as one of the great centers where such birds gather in the West, so that information regarding the migratory movements of the large numbers of birds that visit this region is of interest and importance. In the period from 1914 to 1916, the writer, while engaged in the study of an alkali poisoning prevalent arnong waterfowl in the Salt Lake marshes, had opportunity to band and release a considerable number of ducks and other birds (Pl. I, Fig. 2), a fair proportion of which were killed subsequently in oth regions.

Reports already published ${ }^{1}$ have dealt with the so-called duck sickness, and have detailed methods by which a considerable number of the birds affected were cured. Before such individuals were set at liberty each was marked with a numbered band, and record made

${ }^{1}$ Reports made on the author's investigations of the duck sickness in Utah are contained in bulletins of the United States Department of Agriculture as follows: No. 217, Mortality among Waterfowl around Great Salt Lake, Utah (Preliminary Report), 10 p., 3 pls., 1915 ; and No. 672, The Duck Sickness in Utah, 25 p., 4 pls., 1918 . Other reports based in part on investigations then made are contained in Bulletin No. 793, Lead Poisoning in Waterfowl, 12 p., 2 pls., 1919; and No. 936, Wild Ducks and Duck Foods of the Bear River Marshes, Utah, 20 p., 4 pls., 1921.

Nоте,- This bulletin is a report on a study of the migratory movements of waterfowl and other birds, based on banding operations carried on in Utah from 1914 to 1916 . It is for the information of sportsmen, ornithologists, and others interested in bird migration and the protection of game birds. 
of the number, the species of bird, and the date of release. In addition to wild ducks, numbers of young of other marsh birds were marked in a similar manner before they were able to fly. The release of these banded birds was given publicity, and reports on bands recovered have been received from widely scattered sections in the United States and even from Canada and Mexico. An account of these records is presented in detail in this bulletin.

Bands were placed on 1,241 individuals of 23 species of birds of large or medium size belonging to various families, the majority on wild ducks of 9 species. The bands used were of two kinds,

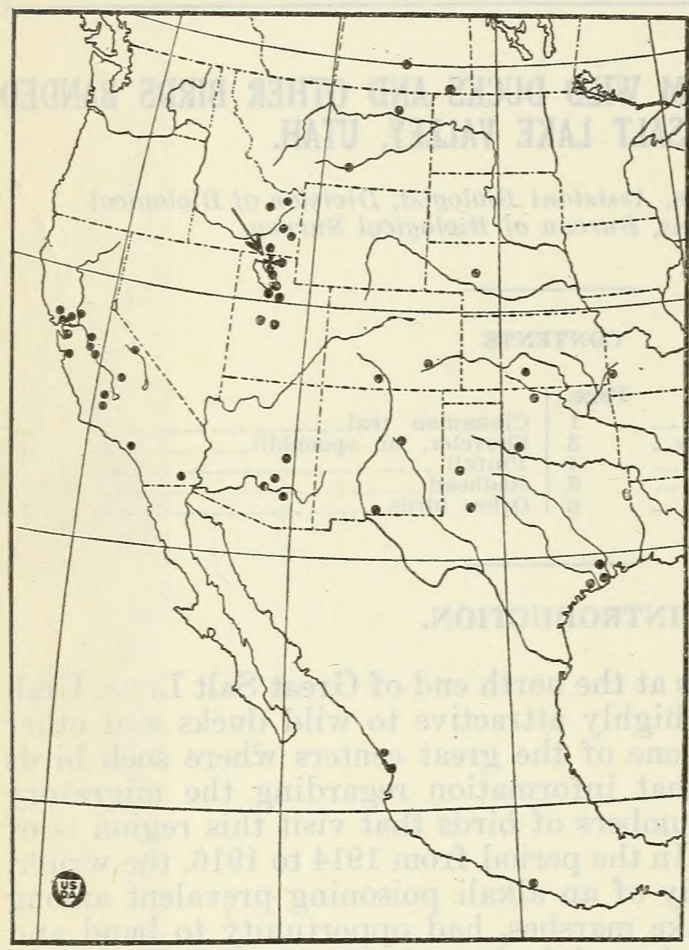

B2II8M

Frg. 1.-Map of the western United States showing migrations of ducks and other wild birds banded in the Salt Lake Valley, Utah, in three years, 19141916 , return records to 1923 . The place of banding and release is marked by a cross (position indicated by an arrow). Localities where banded birds were later recovered are indicated by round dots, a single dot in some cases representing several returns.

The thicker bands are now being employed by the Biological Survey

All birds banded as a basis for the present study were released near the Duckville Gun Club, at the mouth of Bear River, Utah, save for a few that in 1916 were given to the State fish and game commission for exhibition at the annual State fair in Salt Lake City; these were subsequently released near Geneva, Utah, on the shore of Utah Lake. Of the 1,241 birds that were banded, 182 returns have been received, or somewhat more than 14 per cent. 
Of the whole number banded, 994 were ducks, of which 174 were recovered. The number of returns from birds of this group, a little more than 17 per cent, indicates the results that may be obtained from work in banding birds of this family.

In considering these records it is to be borne in mind that many of the birds banded at the mouth of Bear River, Utah, were individuals that had not bred there. Drake pintails and a few mallards begin to come in to that region after the first week in June and continue to gather, perhaps from points far distant, from then until late in fall. Migration out to other points begins about the first week in September, and there is a constant shifting of the waterfowl population during the fall as birds arrive from the north or leave for other points. The Bear River bays begin to freeze about Thanksgiving time, and in normal years by December 1 ducks are forced out of this region, although an occasional open winter may permit their sojourn until in January or later. A few remain to winter in Utah in sloughs or channels kept open by spring water, but the majority perform extended flights to other regions. Some of the wintering mallards pass a short distance northward into the Snake River drainage in Idaho.

Returns from all the records cover a vast area (see Fig. 1) extending from western Missouri and Kansas west to California, and from southern Mexico (Guerrero) to Saskatchewan, Canada. A study of the results indicates one general line of flight to the west from the Salt Lake Valley to California, a route followed by green-winged teals and shovelers and part of the mallards and pintails. Another line of flight, taken by a group of birds that includes cinnamon teals, redheads, pintails, and mallards, crosses to the Great Plains region and thence south into Texas. Indications are that some of the birds last mentioned fly north and east to cross the divide separating Snake River from the headwaters of the Missouri and follow down east of the foothills of the Rocky Mountains; that all pursue such a route is doubtful, since there is nothing to prevent a direct flight to the east or southeast across any of the mountain passes. There is also a third general migration southward over the Rocky Mountain Plateau, probably by a comparatively small number of birds, that carries the snowy herons and some of the ducks through the scattered lakes and ponds found in central and southern Utah, New Mexico, and Arizona.

\section{MIGRATION AND OCCURRENCE RECORDS.}

Following is a list of species from which there have been no returns, with figures to indicate the number of individuals banded and set at liberty:

Banded.

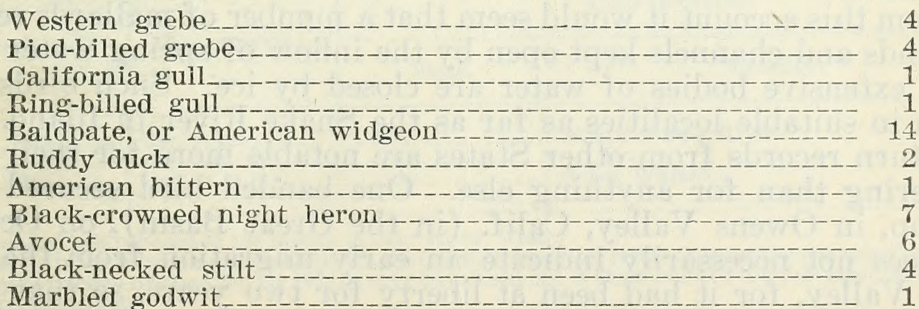


Species from which returns have been received are as follows, the numbers in the first column following each indicating the number of individuals banded, and in the second the number recovered and reported upon:

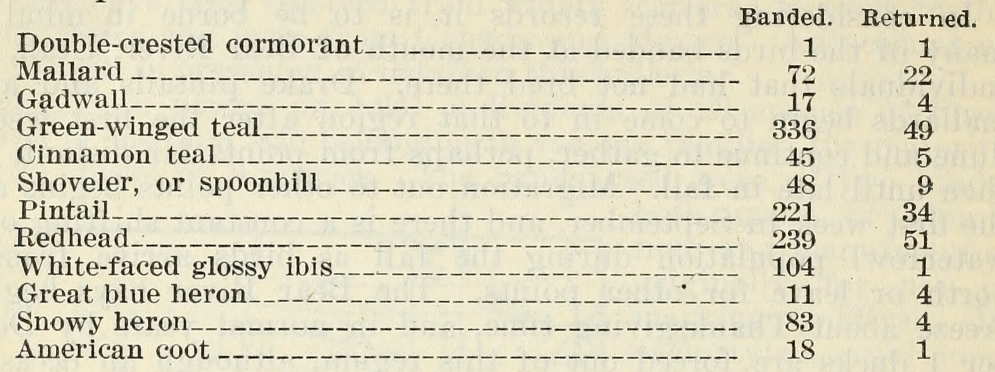

MALLARD.

In comparison with some of the other species of ducks, the number of mallards handled was comparatively small, as only 72 were banded and released during the three seasons in which this work was carried on. Of these, 22-a little more than 30 per cent-were killed and reported subsequently (see Table 1 ). Seven were secured near the mouth of Bear River within a few miles of their place of release, 6 of them, and possibly 7, during the fall in which they had been marked. The other 15 individuals divide into two main groups, one of birds that remained until late fall or winter in the same general region as the mouth of Bear River, and the other of birds that made extended migrations to other regions.

In October two mallards marked during the preceding month were taken on Bear River near Tremonton, not far in an air line from the mouth of the stream. During November these ducks may wander more extensively, as, though several were taken during this month near the mouth of Bear River and one a short distance from Tremonton, others were reported in the sloughs near Great Salt Lake, west of Salt Lake City, and on Utah Lake, near Provo. In addition to these, late in November one was secured near Logan, Utah, and another on Snake River, in Fremont County, Idaho. Records for De" cember are more widely scattered. One bird was killed on Bear River, near Collinston, December 13, and another on the Logan River, in Cache Valley, December 28. In the same month a drake was shot far to the south, on the Sevier River, north of Delta, Utah. During January one was taken near Pebble, Bannock County, Idaho, on the 14th, and another near Stone, in the same State, on the 19th. The latter bird was free from June 17, 1915, to January 19, 1917.

From this account it would seem that a number of mallards remain in ponds and channels kept open by the inflow of spring water after more extensive bodies of water are closed by ice. Such birds pass north in suitable localities as far as the Snake River in Idaho.

Return records from other States are notable more for their wide scattering than for anything else. One banded bird secured near Bishop, in Owens Valley, Calif. (in the Great Basin), on October 16 , does not necessarily indicate an early migration from the Salt Lake Valley, for it had been at liberty for two years, so that there is no certainty that it had come from Utah the year it was killed. 
A second bird was taken about March 1 in southeastern New Mexico, and a third on December 28, west of Houston, Tex. Part of the mallards from Salt Lake Valley, therefore, go west into California and part into the drainage basins leading into the western part of the Gulf of Mexico.

TABLE 1.-Record of returns for banded mallards.

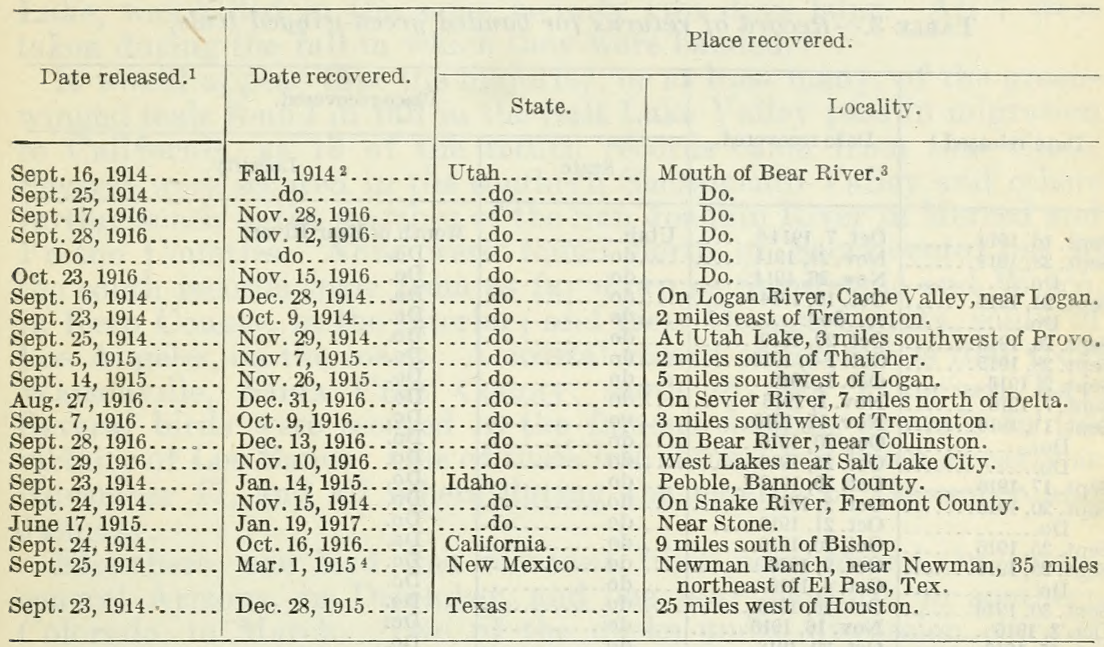

1 All banded and released at the mouth of Bear River, Utah.

2 This bird and the one following were killed some time after November 1, of the year in which marked. 3 The band of one other mallard killed here late in the fall of 1915 was lost, so that information as to date of banding is not available.

${ }^{4}$ Approximate date.

\section{GADWALL.}

Only 17 gadwalls were banded during the course of this work, but of these, returns came from 4 individuals (see Table 2). As all were killed in the immediate vicinity of the mouth of Bear River during the year in which they were released (except possibly in one instance), they offer nothing in regard to possible lines of migration of the species. Only one of the records is worthy of commentan individual that was given its freedom August 27, 1916, and was killed below Willard, Utah, about October 12, 1916. Others lived at liberty only a comparatively short time.

TABLE 2.-Record of returns for banded gadwalls.

\begin{tabular}{|c|c|c|c|}
\hline \multirow{2}{*}{ Date released. ${ }^{1}$} & \multirow{2}{*}{ Date recovered. } & \multicolumn{2}{|r|}{ Place recovered. } \\
\hline & & State. & Locality. \\
\hline 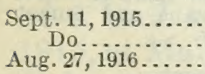 & $\begin{array}{l}\text { Oct. } 1,1915 \ldots \ldots \\
\text { Oct. } 1-8,1915 . \ldots \\
\text { Oct. } 12,1916^{3} \ldots\end{array}$ & 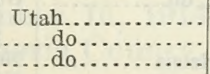 & $\begin{array}{l}\text { Mouth of Bear River. }{ }^{2} \\
\text { Do. } \\
\text { Below Willard. }\end{array}$ \\
\hline
\end{tabular}

1 All banded and released at the mouth of Bear River, Utah.

2 The band taken from one gad wall killed in the fail of 1915 was lost before the number was recorded. This bird may have been released during 1915 or may have been one of three marked the previous year.

3 Approximate date. 


\section{GREEN-WINGED TEAL.}

\section{PL. II, FIg. 1.}

Of the total number of birds banded, 336, or slightly more than one-fourth, were green-winged teals, and 49 of these have been reported by hunters (see Table 3). Among 23 of these birds killed

TABLE 3.-Record of returns for banded green-winged teals.

\begin{tabular}{|c|c|c|c|}
\hline \multirow{2}{*}{ Date released. ${ }^{1}$} & \multirow{2}{*}{ Date recovered. } & \multicolumn{2}{|r|}{ Place recovered. } \\
\hline & & St & Locality. \\
\hline Sept. 16, & Oct. 7,1914 & Utah.. & Mouth of Bear River. \\
\hline Sept. 23, 1914. & Nov. $24,1914$. & ..... do. & Do. \\
\hline Sept. $24,1914$. . & $\begin{array}{l}\text { Nov. } 26,1914 \text {. } \\
\text { Oct. } 10,1914^{2} \text {. }\end{array}$ & $\begin{array}{l}\text {.....do. } \\
\ldots \text {... do. }\end{array}$ & $\begin{array}{l}\text { Do. } \\
\text { Do. }\end{array}$ \\
\hline Do. & $\ldots$ do ${ }^{2} \because \ldots . .$. & & Do. \\
\hline $\begin{array}{l}\text { ept. } 26,191 \\
\text { ept. } 28,191\end{array}$ & $\begin{array}{l}\text { Oct. } 20,1916 . \\
\text { Oct. } 1-8,1915\end{array}$ & do. & Do. \\
\hline t. 2,1916 & $\begin{array}{l}\text { Oct. } 1-8,1915 \\
\text { Oct. } 1,1916 . .\end{array}$ & do. & $\begin{array}{l}\text { Do. } \\
\text { Do. }\end{array}$ \\
\hline & Nov. $1,1916^{2}$. & . do.. & $\begin{array}{l}\text { Do. } \\
\text { Do. }\end{array}$ \\
\hline pt. 11,191 & Nov. 17,1916 & do. & Do. \\
\hline $\begin{array}{l}\text { Do.. } \\
\text { Do.. }\end{array}$ & $\begin{array}{l}\text { Oct. } 20,1916 . \text {. } \\
\text { Oct. } 25,1916\end{array}$ & do. & Do. \\
\hline Sept. 1 & $\begin{array}{l}\text { Oct. } 25,1916 \ldots \\
\text { Oct. } 20,19172 .\end{array}$ & $\begin{array}{l}\text { do. } \\
\text { do }\end{array}$ & $\begin{array}{l}\text { Do. } \\
\text { Do. }\end{array}$ \\
\hline Sept. 2 & Oct. $2,1916 \ldots$ & do. & Do. \\
\hline Do & Oct. 21, 1916. & do & Do. \\
\hline Sept. 2 ? & $\begin{array}{l}\text { Oct. } 20,1916 . \\
\text { Oet. } 9,1916 . .\end{array}$ & do. & $\begin{array}{l}\text { Do. } \\
\text { Do. }\end{array}$ \\
\hline Sept. 30 & Oct. $4,1916 \ldots$ & do. & $\begin{array}{l}\text { Do. } \\
\text { Do. }\end{array}$ \\
\hline ept. 3 & Oct. 10,1916 & do. & Do. \\
\hline 15, & Nov. $16,1916$. & ..do. & Do. \\
\hline $\begin{array}{l}15,1916 \\
23,1916\end{array}$ & Oct. $29,1916$. & ..do. & Do. \\
\hline $\begin{array}{ll}\cdots \\
\cdots\end{array}$ & $\begin{array}{l}\text { Nov. } 20,1916^{2} \\
\text { Oct. } 31,1916 \ldots\end{array}$ & . do & $\begin{array}{l}\text { Do. } \\
\text { Do. }\end{array}$ \\
\hline $\begin{array}{l}\cdots \\
\cdots\end{array}$ & Dec. $21,1914 .$. & do & New Moon Gun Clul \\
\hline$\cdots$ & Dec. $21,1915$. & do & Near mo \\
\hline t. 11,191 & Oct. 20,1916 . & do & Sloughs west of Salt Lake City. \\
\hline Sept. 2 & Nov. 17,1 &.. $\mathrm{~d}$ & $\begin{array}{l}\text { Junction of Mill Creek and Jordan River, } \\
\text { near Salt Lake City. }\end{array}$ \\
\hline $\begin{array}{l}\text { Oct. } 10,1916 \\
\text { Sept. } 30,191\end{array}$ & Oct. 12, 1916 . & $\ldots$ do & \\
\hline 1. 00,1 & $\begin{array}{l}\text { Nov. } 1,1916 \\
\text { Nov. } 13,19\end{array}$ & $\begin{array}{ll}\ldots . . \mathrm{do} \\
\ldots . \mathrm{do}\end{array}$ & $\begin{array}{l}\text { North channel at mouth of Weber River. } \\
\text { Mouth of Weber River. }\end{array}$ \\
\hline & Jan. 28, 191 & Californ & Yolo County, 5 miles from Sacramento \\
\hline sept. 23,19 & Jan & do & Big Lake, 1 mile from Clarksburg, Yolo \\
\hline $\begin{array}{l}\text { ept. } 2,191 \\
\text { ept. } 16,19\end{array}$ & Jan. 27,1917 & ..do. & Near Rutherford. \\
\hline & & & $\begin{array}{l}\text { Harvey Gun Club grounds, at junction of } \\
\text { Cordelia and Suisun Sloughs. }\end{array}$ \\
\hline $\begin{array}{l}\text { Do } \\
\text { ept. } 3\end{array}$ & Jan. 1 & a & Near Gustin, Merced County. \\
\hline $\begin{array}{l}\text { pt. } 30 \\
\text { Do. }\end{array}$ & $\begin{array}{l}\text { Jan. } 28,1917 . . \\
\text { Jan. } 27,1918 . .\end{array}$ & do. & $\begin{array}{l}\text { Near Ingomar, Merced County. } \\
\text { Near Los Baños. }\end{array}$ \\
\hline t. 29 & Dec. 10,1916 . & do. & 7 miles southeast of Los Baños. \\
\hline int & Dec. 16, & do & 8 miles southeast of Los Baños. \\
\hline 3,1916 & $\begin{array}{l}\text { Jan. } 10,191 \\
\text { Dec. } 2,191\end{array}$ & do & $\begin{array}{l}\text { Near Los Banos. } \\
\text { Near Brito, Merced County. }\end{array}$ \\
\hline & Jan. 28,191 & …...do & Do. \\
\hline Oct & Dec. 10,19 & ......do & $\begin{array}{l}\text { Mouth of Pajaro River near Watsonville, } \\
\text { Santa Cruz County. }\end{array}$ \\
\hline $\begin{array}{l}\text { ept. } 7,191 \\
\text { ept. } 16,19\end{array}$ & Dec. 27,191 & .....do do & $\begin{array}{l}\text { Near Maricopa, Kern County. } \\
\text { Near Porterville. }\end{array}$ \\
\hline $\mathrm{Se}$ & Jan. 16, 1916 & .....do do & $\begin{array}{l}12 \text { miles northwest of Waseo, Kern County } \\
\text { (section } 13 \text {, township } 25 \text { south, range } 23\end{array}$ \\
\hline $\begin{array}{l}\text { Sept. } 23 \\
\text { Aug. } 20\end{array}$ & Jan. & ..... do & $\begin{array}{l}\text { east). } \\
\text { Semitropic. }\end{array}$ \\
\hline Aug. 2 & Dec. & $\omega^{-1}$ & $\begin{array}{l}\text { On holdings of Chico Land \& Water Co., } \\
\text { Orange County, } 33 \text { miles below Los } \\
\text { Angeles. }\end{array}$ \\
\hline Sept. 16, 1914 . & Nov. $17,1915$. & .....do... & $\begin{array}{l}\text { Gun club of Christopher Land \& Water } \\
\text { Co., between Santa Ana and Sunset } \\
\text { Beach, Orange County. }\end{array}$ \\
\hline Sept. 28,1 & Dec & Arizon & $\begin{array}{l}\text { Beach, Orange C } \\
\text { Near Miami. }\end{array}$ \\
\hline & $\mathrm{Ma}$ & Colora & Near Sanford, Conejos County. \\
\hline
\end{tabular}

1 All banded and released at the mouth of Bear River, Utah, unless otherwise indicated.

I Approximate date.

3 Released near Geneva, Utah, on Utah Lake. 
near their place of release (near the mouth of Bear River), 21 were taken during the fall in which they were set free, after periods varying from a few days to more than a month. Two, however, survived for slightly more than a year, only to be taken in this same region. Seven others were reported from Utah, 2 from the mouth of the Weber River, and 4 from the marshes along the Jordan River or the sloughs west of Salt Lake City. One, set at liberty on Utah Lake, was killed in the same vicinity two days later. All 7 were taken during the fall in which they were banded.

It would appear that the majority, or at least many, of the greenwinged teals found in fall in the Salt Lake Valley pass in migration to California, as 19 of the return records came from that State. Several were secured in the southern Sacramento Valley and others farther south in the marshes of the San Joaquin River in Merced and Fresno Counties. None were found north of Sacramento, but to the south records come from as far down as Semitropic and Wasco, in Kern County, in the interior; and from Orange County, south of Los Angeles, on the coast. A coastal record of interest is that from Watsonville, Santa Cruz County, south of San Francisco Bay. Several birds were secured in the famous ducking grounds in the vicinity of Los Baños. One of these individuals was taken as early as November 17, and all others during the months of December and January.

Elsewhere, one bird was recorded from near Miami, in southcentral Arizona, in December, and one near Sanford, in southern Colorado, in March. Two of the ducks under discussion enjoyed their liberty for 24 and 27 months, respectively, before they were killed. Others were retaken during the winter following their release.

To summarize the data presented, it would appear that the majority of the green-winged teals leave Utah to winter in California, a few are found in Arizona, and a few returning north in spring pass through Colorado, at least along the upper courses of the Rio Grande.

\section{CINNAMON TEAL.}

Five return records were received from 45 banded individuals of the cinnamon teal, a small number, but one that includes notes of considerable interest. One released October 3, 1916, was taken in the same vicinity three days later. Another, banded September 2, 1916, was more fortunate, as it was not captured until October 1, 1917, more than a year later, when it was shot 3 miles north of the Duckville Gun Club, in the same marshes, in which it had been set free: its travels during that year may be only conjectured. One banded September 1, 1916, was taken November 4, 1916, near the mouth of the Weber River, and another, marked September 4, 1916, was secured subsequently at the Rudy Duck Club in the marshes at the mouth of the Jordan River, on October 8, 1916. The fifth record is that of a bird released September 16, 1914, and recovered January 20, 1915, at Mainer Lake, Brazoria County, Tex., a short distance west of Galveston. 
Though the slender evidence available indicates a migration of this species from northern Utah to the Gulf coast of Texas, it is probable that with further data some birds marked in the same region will be recovered in California. Normally, the majority of the cinnamon teals leave the region around Great Salt Lake before the 1st of October, so that only straggling individuals are found later, after the opening of the shooting season.

TABLE 4.-Record of returns for banded cinnamon teals.

\begin{tabular}{|c|c|c|c|}
\hline \multirow{2}{*}{ Date released. ${ }^{1}$} & \multirow{2}{*}{ Date recovered. } & & Place recovered. \\
\hline & & State. & Loca \\
\hline $\begin{array}{l}\text { Oct. } 3,1916 . \text {. } \\
\text { Sept. 1, } 1916 . \\
\text { Sept. 2, } 1916 .\end{array}$ & $\begin{array}{l}\text { Oct. } 6,1916 . \text { } \\
\text { Nov. } 4,1916 . \\
\text { Oct. } 1,1917 .\end{array}$ & $\begin{array}{l}\text { Utah. } \\
\text {...do. } \\
\ldots \text {..do. }\end{array}$ & $\begin{array}{l}\text { Mouth of Bear River. } \\
\text { Near mouth of Weber River. } \\
\text { Bear River marshes, } 3 \text { miles north of Duck- } \\
\text { ville Gun Club. }\end{array}$ \\
\hline $\begin{array}{l}\text { Sept. } 4,1916 \ldots \\
\text { Sept. } 16,1914 .\end{array}$ & $\begin{array}{l}\text { Oct. } 8,1916 \ldots \\
\text { Jan. } 20,1915 .\end{array}$ & ...do.. & $\begin{array}{l}\text { Marshes at mouth of Jordan River. } \\
\text { Mainer Lake, Brazoria County, west of } \\
\text { Galveston. }\end{array}$ \\
\hline
\end{tabular}

${ }_{1}^{1}$ All banded and released at the mouth of Bear River, Utah.

\section{SHOVELER, OR SPOONBILL.}

The percentage of returns on banded shovelers, or spoonbills, was slightly higher than in the case of the cinnamon teal, as from a total of 48 birds released 9 were subsequently reported (see Table 5). Six of these were killed in the Bear River marshes (several in South Bay, one on the Salt Creek marshes, and one on the Chesapeake Bay) from a few days to several weeks after they had been banded. One was captured at the mouth of the Weber River, and another at the mouth of the Jordan, near Salt Lake City. The remaining bird was taken near Vallejo, Calif., nearly 14 months after it had been released. From this slight evidence it appears that some spoonbills migrate from Utah to pass the winter in California.

TABLE 5.-Record of returns for banded shovelers.

\begin{tabular}{|c|c|c|c|}
\hline \multirow{2}{*}{ Date released. ${ }^{1}$} & \multirow{2}{*}{ Date recovered. } & $39=$ & Place recovered. \\
\hline & & State. & Locality. \\
\hline $\begin{array}{r}\text { Sept. } 29,1914 \ldots . \\
\text { Sept. } 1,1916 \ldots . \\
\text { Sept. } 25,1916 \ldots \\
\text { Sept. } 28,1916 \ldots \\
\text { Do...... } \\
\text { Do...... } \\
\text { Do } \ldots \ldots \ldots \\
\text { Sept. } 29,1916 \ldots \\
\text { Sept. } 1,1916 \ldots .\end{array}$ & $\begin{array}{l}\text { Oct. } 17,1914 \ldots \\
\text { Oct. } 12,1916 \ldots \\
\text { Oct. } 7,1916 \ldots . \\
\text { Oct. } 1,1916 \ldots . \\
\text { Oct. } 8,1916 \ldots . \\
\text { Oct. } 7,1916 \ldots . \\
\text { Oct. } 21,1916 \ldots \\
\text { Oct. } 20,1916^{2}{ }^{2} . \\
\text { Oct. } 28,1917 \ldots\end{array}$ & 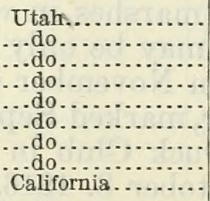 & $\begin{array}{l}\text { Mouth of Bear River. } \\
\text { Do. } \\
\text { Do. } \\
\text { Do. } \\
\text { Do. } \\
\text { Do. } \\
\text { Mouth of Weber River. } \\
\text { Mouth of Jordan River. } \\
\text { Near Vallejo. }\end{array}$ \\
\hline
\end{tabular}

1 All banded and released at the mouth of Bear River, Utah.

2 Approximate date. 


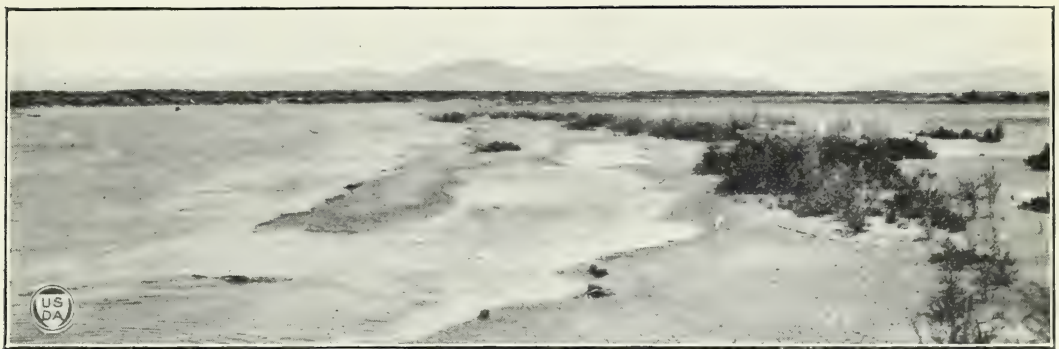

FIG. I.-MOUTH OF BEAR RIVER, UTAH.

B1622

View across marshes and mud fiats near northern end of Great Salt Lake.

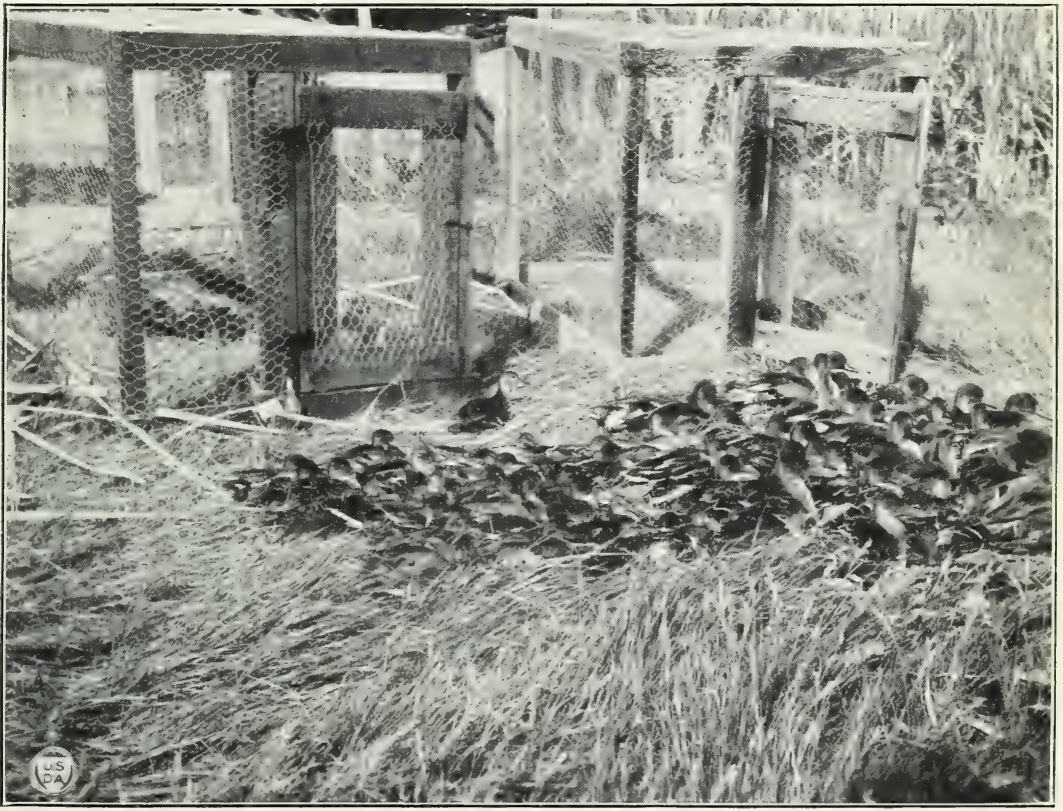

FIG. 2.-SiCK DUCKS AT LABORATORY PEN.

817153

Many of these recovered in a few days and were released, each bearing a numbered band on one leg. (Photograph taken near mouth of Bear River.) 


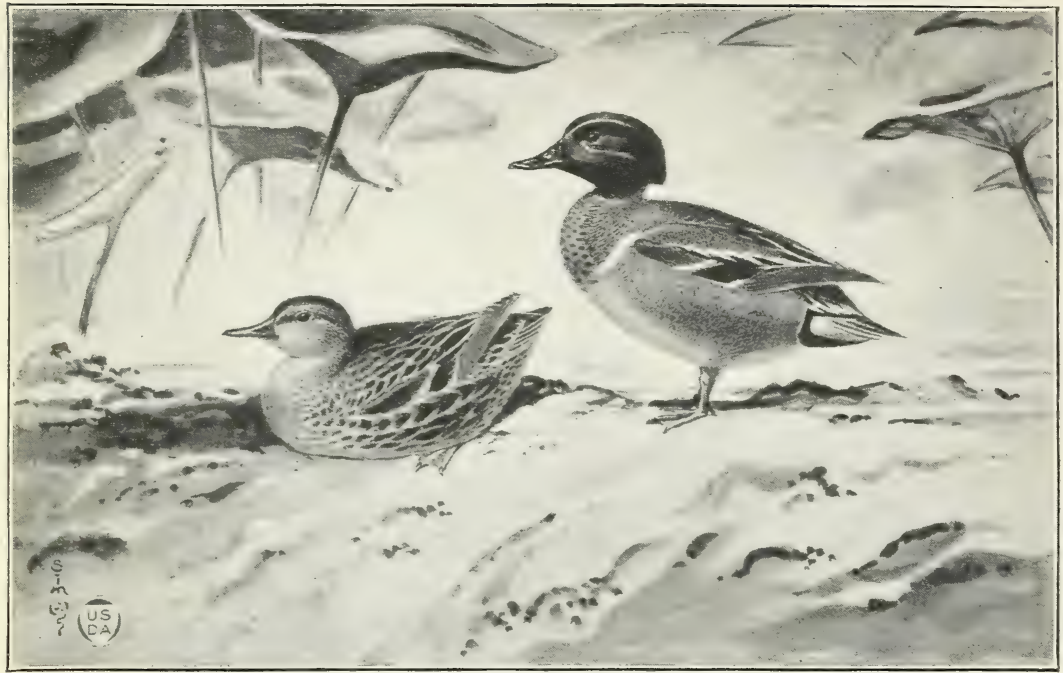

Fig. I.-Green-Winged Teals.

$B 1366 \mathrm{M}$

Male at right; female at ieft. Bands were placed on 336 of these birds, and of this number 49 were subsequently recovered.

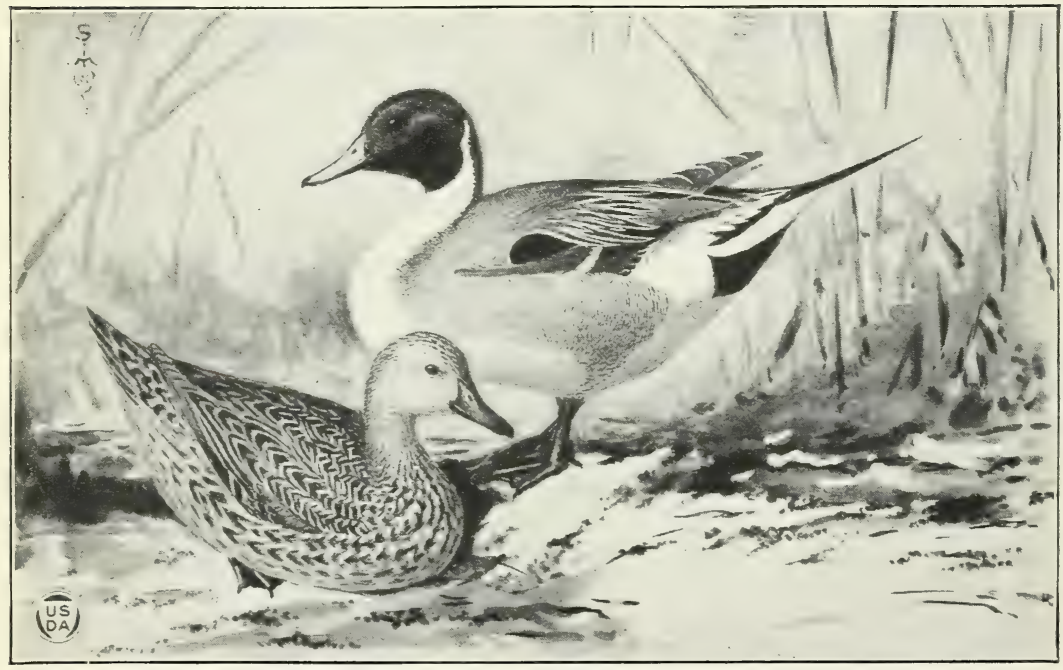

FIG. 2.-PINTAILS.

Male at right; female at left. Reports were received on 34 of the 221 banded pintails released. 


\section{PINTAIL.}

PL. II, FIG. 2.

While only 34 bands have been returned from a total of 221 pintails released, the distribution shown is the most remarkable of any of the birds included in the present account (see Table 6). Only 7 banded pintails were killed near the mouth of Bear River, 5 during October of the fall in which released, 1 probably secured in November, and 1 in April of the following spring. Other records for Utah come from Bear River, a few miles above its mouth, the mouth of the Weber River, the Jordan River, and the marshes west of Salt Lake City, 4 during October and 3 during November of the fall of their release. Another killed near the mouth of the Jordan River was at liberty from September 29, 1916, until late in November, 1920.

Many pintails apparently migrate in winter to the interior ralleys of California, as shown by 8 returns from the area between the marshes above Suisun Bay and the Imperial Valley south of Calipatria. As might be expected, several of these birds were shot in the extensive marshes of the San Joaquin River, in Merced and Fresno Counties. One bird released August 20 was killed October 16 near Dos Palos, Merced County, indicating an early migration. while 2 others were secured in November. Two were noted in December and 3 in January, months when in normal years pintails should all be absent from Utah.

Proper interpretation and presentation of data from States farther east is more difficult. The evidence indicates a line of flight to the northward to the drainage of the Missouri River, as one of the marked birds was secured near Glasgow, Mont., on September 15, 11 days after its release. Another fall record from farther south is that of a bird from near Hyannis, in the sandhill region of $\mathrm{Ne}$ braska. A report from near Markham, on the Gulf coast of Texas, would seem to indicate a bird in its winter home. In the region from the Mississippi River westward to the Great Plains, numbers of pintails linger through the winter south of the line of ice and, with the coming of open water in the earliest of spring thaws, crowd eagerly northward during favorable weather, perhaps to be driven southward again in a few days by a sudden freeze that closes the streams and ponds. Their numbers are increased late in January by birds coming from winter homes farther south. Reports from Oklahoma and eastern New Mexico at the end of January, and from the panhandle of Texas near the end of February, are supposed to represent such restless early migrants.

One of these migrants, a bird captured on the salt plains of the Salt Fork of the Arkansas River, in Oklahoma, had a history of unusual interest. In September, 1914, a pintail helpless with the duck sickness was noted on the flats of South Bay, as the writer was crossing in a mud boat-a flat-bottomed launch fitted with steel-bladed paddle wheels on either side and driven by an automobile engine, designed to run over smooth clay mud barely corered with water. A motion to the steersman was sufficient to change the course slightly, so that, dashing past in a spray of mud and water, a veritable charging juggernaut, it was possible to lean out, seize the duck, and draw it in. A peculiar crescent of white 
feathers marked this individual duck from others, so that it was easily recognized. On September 23, after a week or two in captivity, the bird, now fairly tame, was banded and released. For a month it lingered about the duck pens, though the shooting season was on, and returned night and morning to be fed until late in October, when the laboratory was closed for the season. About February 1, 1915, this bird was captured in Oklahoma, and on March 6 of the same year was reported still alive and in captivity.

TABLE 6.-Record of returns for banded pintails.

\begin{tabular}{|c|c|c|c|}
\hline \multirow{2}{*}{ Date released. $a$} & \multirow{2}{*}{ Date recovered. } & \multicolumn{2}{|r|}{ Place recovered. } \\
\hline & & State or Province. & Locality. \\
\hline Sept. 16, 1914. & Oct. $10,1914$. & Utah... & Mouth of Bear River, Utah. \\
\hline $\begin{array}{l}\text { Do........ } \\
\text { ept. } 23,1914 \ldots\end{array}$ & iate fall 1914. & ...... do & Do. \\
\hline ері. 23,1 & $\mathrm{Oc}$ & & Do. \\
\hline 7,1916 & Oct. 4,1916 . & $\ldots d$ & $\begin{array}{l}\text { Do. } \\
\text { Do. }\end{array}$ \\
\hline Oct. 10,1916 & April, 1917 & dos & Do. \\
\hline 15,1916 & Oct. $15,1916 d$. & d & Do. \\
\hline Sept. 28, 1914 & Oct. $9,1914 b$.. & .....do.. & Near Bear River City, Boxelder County. \\
\hline $\begin{array}{l}\text { Do } \\
\text { Do }\end{array}$ & $\begin{array}{l}\text { Oct. 18, } 1914 \text {. } \\
\text { Oct. } 19,1914 \text {. }\end{array}$ & d & Third Creek between Hooper and Warren. \\
\hline Do & Nov. 14,1914 & do. & Central Gun Club, west of Salt Lake City. \\
\hline Oct. 10,1916 & Nov. 15,19 & do & Black Marsh, near Salt Lake City. \\
\hline Do.c..... & Oct. $24,1916 \ldots$ & .....do. & 4 miles north of Brigham City. \\
\hline Sept. 29,1916 & $\begin{array}{l}\text { Nov. } 15,1916 \ldots . . . . \\
\text { Late November, }\end{array}$ & $\begin{array}{l}\text {...... do... } \\
\text {..... do.. }\end{array}$ & $\begin{array}{l}\text { Mouth of Jordan River. } \\
\text { Do. }\end{array}$ \\
\hline ent 16 & Apr. 13, 1916. & Saskatc & Near Expanse. \\
\hline & Date uncertain & $\cdots$ & Estevan. \\
\hline s & Sept. $15,1916 \ldots$ & Montan & Mahon-Hoyt Reservoir, 6 miles southeast of \\
\hline ept. 16, 1914 & Nov & Nebras & $\begin{array}{l}\text { Glasgow. } \\
14 \text { miles north of Hyannis. }\end{array}$ \\
\hline & Date & Oklaho & Near Elmer, Jacks \\
\hline ot. 2 & Feb. 1, 1915 b & $\because$ & Salt Plains of Alfalfa \\
\hline & Jan. 26,19 & & 2 miles north of Asbu \\
\hline Sept. 25 & Jan. 26, 191 & Texas. & Near Markham, Matagorda County. \\
\hline 20, & Feb. 25, 1 & …un. & Olton, Lamb County. \\
\hline Aug. & Jan. 29,19 & New $M$ & Arroyo Pecos, $2 \frac{1}{2}$ miles south of Las Vegas. \\
\hline $\begin{array}{l}\text { Aug. } 27, . \\
\text { Do.. }\end{array}$ & December, 191 & Arizon & Near Show Low. \\
\hline Do & Dec. 5,191 & Califor & Near Eden. \\
\hline $\begin{array}{l}\text { t. } 17,19 \\
\text { t. } 10,19\end{array}$ & Nov. $20,1916$. & ......do do & Near Cordelia, Solano County. \\
\hline g. 20,19 & Oct. $16,1916$. . & & $\begin{array}{l}\text { Near Alvarado. } \\
\text { Near Dos Palos. }\end{array}$ \\
\hline Do. & Jan. $29,1917$. & do. & Near Brito, Merced County. \\
\hline ag. 2 & Jan. 24, 1915 & & Fresno County. \\
\hline ag. 2 & $\begin{array}{l}\text { Jan. } 27,1918 . \\
\text { Dec. } 2-8,1917\end{array}$ & $d$ & Buena Vista Lake, near Bakersfield. \\
\hline & $2-8$, & & Imperial Valley, soutl \\
\hline
\end{tabular}

a All banded and released at the mouth of Bear River, Utah, unless otherwise indicated.

$b$ Approximate date.

$c$ Released near Geneva, on Utah Lake, Utah.

$d$ Reported December 5, 1917 .

$e$ Reported March 6, 1915, as killed "some time ago."

$f$ Killed by a hunter within an hour after release.

The most easterly report of any of the banded ducks was that of a pintail shot on January 26 near Asbury, in western Missouri, presumably another migrant in northward flight. Two records for southern Saskatchewan, Canada, one in April and the other of uncertain date, mark the northern limit from which birds have been reported.

From these data we learn that after leaving Utah part of the pintails go to California to winter in the interior valleys, while others cross to the Great Plains and go southward to the Gulf 
coast in Texas. The spring migration carries the latter individuals northward through the plains again, eastward as far as western Missouri and north at least into southern Canada. Spring records in the Missouri Valley drainage ceased after 1915, as in the following year spring shooting in the United States was prohibited by Federal law, and no further returns came from ducks killed at this season.

It may be noted that only a small part of the pintails found early in the fall in the Salt Lake Valley nest there, as the species is only moderately common as a breeder in that region. Migrants from other regions, probably to the northward, arrive early, even in June, and continue to gather in suitable areas until fall. ${ }^{2}$

Banding records furnish some idea as to the average length of life of a pintail after it reaches maturity. Of birds banded in September, 1914, one was taken in April and one in November, 1916. one in January, 1917, and one in December, 1917. Of those marked from August to October, 1916, one was shot in December, 1917, two in January and one in November, 1918, while one was fortunate enough to escape until the last of November, 1920, a period of slightly more than four years.

\section{REDHEAD.}

Domestic ties in the redhead family are as loose perhaps as among any of the North American ducks. Several females may use one nest for their eggs, and when ducklings appear they are self-reliant little chaps that as often as not start off on adventurous explorations of their own, with no regard for the movements of their mother. The parent may forsake her charges when they are less than half grown, and it is the rule for them to be left to their own devices at an early age. Though like some other children in their lack of respect for parental guidance and opinion, young redheads are gregarious and seek others of the season's hatching, so that they ordinarily travel in company. These inexperienced birds, as they passed the duck pens where birds convalescent from the duck sickness were confined, came over in search of company, and clambered out on shore in an attempt to join the ducks in the cages. Trapping them when they were still unable to fly was an easy matter, so that in 1915 and 1916 many were captured and 239 were banded and released. Fifty-one of these have been reported by hunters (see Table 7 ), more than half, 28 to be exact, being taken in the Bear River marshes, all during the fall of their release.

Most of the birds were marked in August and September. Two of the returns came during the month of September, one from a bird found dead from the duck sickness, and one from an individual drowned accidentally at the duck pens. Twenty-two were killed during October, a number potted by hunters as they passed in boats up or down the river, others shot at points on the bays in the delta of the

2 See U. S. Dept. Agr. Bull. No. 936, pp. 7-8. 
stream or near the river below Corinne. Two were secured on November 5 and two on November 12.

Among 16 other records for Utah, 6 came from the vicinity of Bear River above its mouth, or its larger tributaries within a radius of 50 miles. Five of these returns were secured between October 1 and 17 of the year of their release. A single individual shot November 22 near Honeyville was reported as thin and poor, and may have been diseased or injured in some way. One was killed near the Hot Springs, north of Ogden, on November 18, and 1 near the mouth of the Weber River, on October 29. From a little farther south 3 were reported from Syracuse, near the border of Great Salt Lake, 2 birds shot in company on October 14, and 1 on October $20 ; 2$ were shot on October 2 in the sloughs west of Salt Lake City and another in the same vicinity about the middle of November. In the Narrows of the Jordan River, 20 miles south of Salt Lake City, 1 was killed December 24, 1915, while another was recorded from the Sevier River, near Gunnison, Utah, October 1.

Three marked redheads were secured in eastern Idaho, all in or near the drainage of Snake River. Two of these were shot on October 1 and 15, respectively, and 1 was taken in Bingham County on December 8, more than two years after it was released.

Scattered records from east of the Rocky Mountains have considerable value, as they indicate a line of flight to a winter range. One bird released September 27, 1916, was killed about November 27, near Ordway, in the drainage of the Arkansas River, on the plains of eastern Colorado. Another, banded October 23, 1916, was secured near O'Donnell, Dawson County, western Texas, on November 22. A third, set at liberty August 20, 1916, was killed near Nashville, Kingman County, south central Kansas, April 21, 1917, probably while in northward migration. The last of these distant records, one without apparent connection with the others, is that of an individual released between August 27 and September 27, 1916, and killed January 25, 1919, on the Florence Reservoir, near Florence, Ariz., in the Gila River Basin.

The majority of redheads on the Bear River marshes leave in fall migration between the 1st and 10th of September, and after that only stragglers are found. Indications from returns of banded birds are that the line of flight is eastward, probably to a wintering ground on the Gulf coast of Texas, though no returns have actually come from. that region. It is possible that part of these birds travel northward to the drainage area of the Missouri and then swing southward over the plains, since two records come from eastern Idaho at the proper season to support such belief. Release of young birds late in September, after the bulk of the species has left, may induce more or less aimless wandering among some and account for part of the scattered returns. There is a distinct movement southward along the eastern shore of Great Salt Lake, howerer, for a distance of 60 miles, that may be an indication of a second line of southward flight. December records for Utah and Idaho are perhaps from injured individuals unable to perform extended flights. 
TABLE 7.-Record of returns for banded redheads.

\begin{tabular}{|c|c|c|c|}
\hline \multirow{2}{*}{ Date released.1 } & \multirow{2}{*}{ Date recovered. } & \multicolumn{2}{|r|}{ Place recovered. } \\
\hline & & State. & Locality. \\
\hline Aug. 15, 1915 & Oct. $2,1915$. . & Utah... & Mouth of Bear River. \\
\hline $\begin{array}{l}\text { Sept. } 3,1915 \\
\text { Sept. } 14,1915\end{array}$ & Oct.1-8, 1915 . & .....do... & Do. \\
\hline Sept. 14, 1915 . & …do do... & .... do .. & Do. \\
\hline $\begin{array}{l}\text { Sept. } 20,1915 . \\
\text { Sept. } 25,1915 \text {. }\end{array}$ & $\begin{array}{l}\text { Oct. 17, 1915... } \\
\text { Oct. 3,1915. }\end{array}$ & ......do.. & Do. \\
\hline $\begin{array}{l}\text { Sept. } 25,1915 . \\
\text { Do......... }\end{array}$ & $\mid \begin{array}{l}\text { Oet. } 3,1915 . \ldots . . . \\
\text { Oct. } 1-8,1915 . . .\end{array}$ & (....do.. & $\begin{array}{l}\text { Do. } \\
\text { Do. }\end{array}$ \\
\hline Do......... & .....do.............. & ...... do. & Do. \\
\hline Do...... & & .....do.. & Do. \\
\hline $\begin{array}{l}\text { Do... } \\
\text { Sept. } 28,1915 .\end{array}$ & $\begin{array}{l}\text { Oet. } 1,1915 \ldots \ldots \\
\text { Oct. } 1-8,1915 \ldots . .\end{array}$ & ..... do... & Do. \\
\hline Do.......... & .... do do.............. & 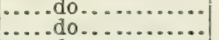 & $\begin{array}{l}\text { Do. } \\
\text { Do. }\end{array}$ \\
\hline & October, 1915. & .....do.. & Do. \\
\hline $\begin{array}{l}\text { Aug. 25, } 1916 . \\
\text { Sept. 2, } 1916 .\end{array}$ & $\begin{array}{l}\text { Oct. } 7,1916 \ldots \\
\text { Oct. } 20,1916 .\end{array}$ & ......do... & Do. \\
\hline Sept. 4, 1916. & $\begin{array}{l}\text { Uct. } 20,1916 . \\
\text { Oct. } 10,1916 .\end{array}$ & $\begin{array}{l}\text {.....do.. } \\
\text {..... do.. }\end{array}$ & $\begin{array}{l}\text { Do. } \\
\text { Do. }\end{array}$ \\
\hline Do...... & October, 1916 & ...... do. & Do. \\
\hline Sept. 7, $1916 \ldots$ & Oct. 2, 1916. & ......do.. & Do. \\
\hline $\begin{array}{l}\text { Do } \\
\text { Sept. } 8,1916 \ldots\end{array}$ & $\begin{array}{l}\text { Oct. } 8,1916 \ldots \\
\text { Nov. } 12,1916 .\end{array}$ & ......do... & Do. \\
\hline Do...... & Sept. $28,1916$. & (.....do... & $\begin{array}{l}\text { Do. } \\
\text { Do. }\end{array}$ \\
\hline Do....... & Oct. 22,1916 .. & ..... do. & Do. \\
\hline $\begin{array}{l}\text { Do } \\
\text { Sept. } 27,1916 \ldots \ldots\end{array}$ & Sept. 29, 1916. & .....do.. & Do. \\
\hline $\begin{array}{l}\text { Sept. } 27,1916 . . \\
\text { Do........ }\end{array}$ & $\begin{array}{l}\text { Oct. } 5,1916 \ldots \\
\text { Oct. } 2,1916 \ldots\end{array}$ & ....do... & $\begin{array}{l}\text { Do. } \\
\text { Do. }\end{array}$ \\
\hline Do....... & $\begin{array}{l}\text { Oct. } 2,1916 \ldots \\
\text { Nov. } 12,1916 .\end{array}$ & .....do.. & $\begin{array}{l}\text { Do. } \\
\text { Do. }\end{array}$ \\
\hline $\begin{array}{l}\text { Do. } \\
\text { Oct. } 15,1916 \text {. }\end{array}$ & Oct. 21,1916 . & .....do.. & Do. \\
\hline $\begin{array}{l}\text { Oct. } 15,1916 . \\
\text { Oct. } 21,1916 .\end{array}$ & $\begin{array}{l}\text { Nov. } 5,1916 . . \\
\ldots \ldots \text { do....... }\end{array}$ & $\begin{array}{l}\text {....do... } \\
\text {....do.. }\end{array}$ & $\begin{array}{l}\text { Do. } \\
\text { Do. }\end{array}$ \\
\hline Aug. $22,1915 \ldots$ & Oct. $1,1915$. & .......do... & $\begin{array}{l}\text { Do. } \\
4 \text { miles west of Logan. }\end{array}$ \\
\hline Sept. $7,1916 \ldots$ & Nov. 22, 1916 & .....do. & Near Honeyville. \\
\hline Sept. $17,1916 \ldots$ & $\begin{array}{l}\text { Oct. } 11,1916 . \\
\text { Oct. } 7,1916^{2}\end{array}$ & do. & \\
\hline & $\begin{array}{l}\text { Uct. } 7,1916{ }^{2} \text {. } \\
\text { Oct. 8, } 1916 . .\end{array}$ & . do. & $\begin{array}{l}3 \text { miles east of Tremonton. } \\
\text { Near Bear River City. }\end{array}$ \\
\hline $\begin{array}{l}\text { Do, } 1716 . \\
\text { Sept. } 17,1916 .\end{array}$ & Oct. 17, 1916. & ..... do. & Do. \\
\hline Sept. 4, 1916. & $\begin{array}{l}\text { Nov. } 18,1916 . \\
\text { Oct. } 29,1916 .\end{array}$ & $\begin{array}{l}\text { (....do. do. } \\
\text {.....do. }\end{array}$ & $\begin{array}{l}\text { Near Hot Springs, Boxelder County. } \\
\text { Mouth of Weber River. }\end{array}$ \\
\hline Do. $7,1916$. & Oct. $20,1916$. & -....do. & Near Syracuse, Davis County. \\
\hline Sept. $7,1916 \ldots$ & $\begin{array}{l}\text { Oct. } 14,1916 . \\
\ldots . \text { do....... }\end{array}$ & $\ldots$ & $\begin{array}{l}\text { Do. }{ }^{3} \\
\text { Do. }\end{array}$ \\
\hline $\begin{array}{l}\text { Aug. } 28,1916 . \\
\text { Sept. 4, 1916.. }\end{array}$ & Oct. $2,1916$. & $\cdots$. & $\begin{array}{l}\text { Sloughs west of Salt Lake City. } \\
\text { Do. }\end{array}$ \\
\hline Aug. 27, 1916 . & Nov 14,1916 & do. & Vicinity of Magna, near Salt Lake City. \\
\hline Aug. 22, 1915 & Dec. 24,191 & & $\begin{array}{l}\text { Narrows of Jordan River, } 20 \text { miles south of } \\
\text { Salt Lake City. }\end{array}$ \\
\hline $\begin{array}{l}\text { Aug. } 15,1915 . \\
\text { Aug. } 27,1916 .\end{array}$ & Oct. 1, 1915. & .....do. & 3 miles west of Gunnison. \\
\hline Aug. 20, & $\begin{array}{l}\text { Oct. } 1,1916 . . \\
\text { Dec. } 8,1918 .\end{array}$ & Idaho $\ldots . . . \ldots \ldots . .$. & $\begin{array}{l}\text { Mud Lake, near Hamer. } \\
\text { Tanner Field Lake, Bingham Countv. }\end{array}$ \\
\hline Sept. 4, & Oct. 15,1916 & 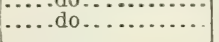 & Blackfoot Swamp, 12 miles north of Soda \\
\hline Sept. 27, $1916 \ldots \ldots$. & Nov. $27,1916 \ldots .$. & Colorado.... & Ordway Lakes, near Ordway. \\
\hline $\begin{array}{l}\text { Aug. 20, 1916. } \\
\text { Oct. } 23,1916 . .\end{array}$ & $\begin{array}{l}\text { Apr. } 21,1917 \ldots \ldots \\
\text { Nov. } 22,1916 . \ldots\end{array}$ & 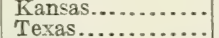 & $\begin{array}{l}\text { Near Nashville, Kingman County. } \\
\text { Near O'Donnell, Dawson County. }\end{array}$ \\
\hline Fall, $1916^{4} \ldots$ & Jan. $25,1919 \ldots \ldots$ & Arizona............... & Florence Reservoir, near Florence. \\
\hline
\end{tabular}

1 All banded and released at the mouth of Bear River, Utah.

2 Approximate date.

3 This hird and the one following were banded and released at the same time and when killed were still in company.

4 Released between August 27 and September 27.

\section{RETURNS FROM OTHER BIRDS.}

Records of fire species of other families of birds may be considered briefly.

An immature double-crested cormorant that was banded on July 3. 1915, was shot near the Jordan River, 12 miles northwest of Salt Lake City, on October 10 of the same year.

Of 11 great blue herons marked in 1916 while in the nest, a return came from one bird. an individual banded July 3, 1916, and killed November 1, 1916, 4 miles southwest of Billings. Mont. The indicated northward movement after the breeding season is in accordance 
with similar habits recorded for little blue herons and egrets in the East.

An American coot, one of 18 marked on August 20, 1916. was shot

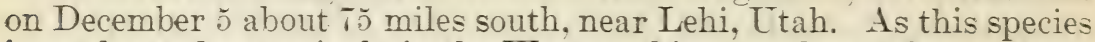
is not hunted extensirely in the West, nothing was heard from others.

Though 104 young white-faced gloss ibises were banded in rookeries where they nested in company with snowy herons, return has come from but 1 indiridual. This bird, marked July 3, 1916, and found sick on the shores of Tulare Lake, Calif., on October 22, 1922. indicates a migration morement from the Salt Lake Talley toward the southwest.

The snomr heron nests in colonies in the lotrer Bear River marshes. and on July 3 and 1t, 1916. 83 nestlings were marked with bands. In March, 1917, a peon at Mexcaltitan. Territory of Tepic, Mexico. brought a bit of aluminum to a Japanese labor contractor. saving that he had found it on the leg of a heron that he had killed and eaten. The band had been preserred out of curiosity, as the peon was unable to read. but chance had brought a return on one of the snowy herons that was marked in Utah the previous year. About June 1, 1917, another snowy heron killed on the Papagayo Lagoon.

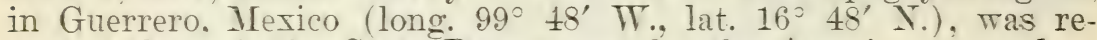
ported through the State Department by the American consul at Acapulco. A third record is of a snowy heron found on the San. Pedro River, in northwestern Cochise County. Ariz., on April 13, 1919: and a fourth is furnished by a heron recorered at Escuinapa. Sinaloa, Mexico, on January 20, 1923.

These dates indicate that the breeding snowy herons of the Salt Lake Valley winter on the mest coast of Mexico. Their route northward mav follow the Colorado River, or birds may scatter in an inland flight that carries them more or less directly northward. In Utah it was observed that though part of the snowy herons arrived early. others continued to join the breeding colonies until late in June, observations that coincide with the late date at which one from this region was secured in Guerrero. 


\section{PUBLICATIONS OF THE UNITED STATES DEPARTMENT OF AGRI- CULTURE RELATING TO GAME BIRDS AND THE DISTRIBUTION AND MIGRATION OF BIRDS.}

\section{FOR FREE DISTRIBUTION BY THE DEPARTMENT.}

Bird Migration. (Department Bulletin 185.)

Eleven Important Wild-duck Foods. (Department Bulletin 205.)

Prepagation of Wild-duck Foods. (Department Bulletin 465.)

The Duck Sickness in Utah. (Department Bulletin 672.)

Food Habits of Seven Species of American Shoal-water Ducks. (Department Bulletin 862.)

Wild Ducks and Duck Foods of the Bear River Marshes, Utah. (Department Bulletin 936.)

Migration Records from Wild Ducks and Other Birds Banded in the Salt Lake Valley, Utah. (Department Bulletin 1145.)

Game Laws for 1922. (Farmers' Bulletin 1288.)

The Great Plains Waterfowl Breeding Grounds and Their Protection. (Yearbook Separate 723.)

Federal Protection of Migratory Birds. (Yearbook Separate 785.)

Conserving Our Wild Animals and Birds. (Yearbook Separate 836.)

Instructions for Bird Banding. (Department Circular 170.)

Directory of Officials and Organizations Concerned with the Protection of Birds and Game, 1922. (Department Circular 242.)

Annual Report of the Governor of Alaska on the Alaska Game Law, 1922. (Department Circular 260.)

Migratory Bird Treaty, Act, and Regulations. (Biological Survey Service and Regulatory Announcement No. 48.)

FOR SALE BY THE SUPERINTENDENT OF DOCUMENTS, GOVERNMENT PRINTING OFFICE, WASHINGTON, D. C.

Mortality Among Waterfowl Around Great Salt Lake, Utah. (Department Bulletin 217.) Price, 5 cents.

Lead Poisoning in Waterfowl. (Department Bulletin 793.) Price, 5 cents.

Game as a National Resource. (Department Bulletin 1049.) Price, 10 cents. 


\section{ORGANIZATION OF THE UNITED STATES DEPARTMENT OF AGRICULTURE.}

Secretary of Agriculture

Assistant Secretary

Director of Scientific Work.

Director of Regulatory Work

Weather Bureau

Bureau of Agricultural Economics

Bureau of Animal Industry.

Bureau of Plant Industry

Forest Service

Bureau of Chemistry

Bureau of Soils

Bureau of Entomology

Bureau of Biological Survey

Bureau of Public Roads

Fixed Nitrogen Research Laboratory

Division of Accounts and Disbursements

Division of Publications

Library

States Relations Service

Federal Horticultural Board

Insecticide and Fungicide Board

Packers and Stockyards Administration

Grain Future Trading Act Administration

Office of the Solicitor

This bulletin is a contribution from-

Bureau of Biological Survey

Division of Biological Investigations

E. W. Netson, Chief.

16
Henry C. Wallace.

C. W. Pugsley.

E. D. BALL.

Charles f. Marvin, Chief. Henry C. Taylor, Chief.

ЈоHN R. MoHLen, Chief.

Wiluiam A. TaYlor, Chief.

W. B. Greeter, Chief.

Walter G. Campbell, Acting Chief.

Milton Whitney, Chief.

L. O. Howard, Chief.

E. W. Nelson, Chief.

Thomas H. MacDonald, Chief.

F. G. Cottreir, Director.

A. Zappone, Chief.

Јонм L. Соввs, Jr., Chief.

Claribel R. Barnett, Librarian.

A. C. True, Director.

C. L. Marlatt, Chairman.

J. K. HAYwOOD, Chairman.

Chester Morrill, Assistant to the Secretary.

R. W. WILliams, Solicitor.

ADDITIONAL COPIES

OF THIS PUBLICATION MAY BE PROCURED FROM

THE SUPERINTENDENT OF DOCUMENTS

GOVERNMENT PRINTING OFFICE

WASHINGTON, D. C . A T

5 CENTS PER COPY

PURCHASER AGREES NOT TO RESELL OR DISTRIBUTE THIS COPY FOR PROFIT.-PUB. RES. 57, APPROVED MAY 11, 1922 

